\title{
Shot Dosing Unit
}

National Cancer Institute

\section{Source}

National Cancer Institute. Shot Dosing Unit. NCI Thesaurus. Code C78753.

A dosing unit equal to the amount of active ing redient(s) contained usually in a syringe or a small cup and is to be administered in full at once. 